\title{
RUMOURS AND REALITIES OF MARRIAGE PRACTICES IN CONTEMPORARY SAMIN SOCIETY (PART II)
}

\author{
Arif Rohman \\ School of Humanities and Social Sciences, Charles Sturt University, \\ Locked Bag 678, Wagga Wagga, NSW, 2678, Australia \\ Email: arohman@csu.edu.au
}

\begin{abstract}
The article 'Rumours and Realities of marriage Practices in Contemporary Samin Society' published on Humaniora (June 2010) confirmed that the myths of the practices of "virginity tests' and 'stray marriages' to be discredited. In contrast, the Samin community through their marriage system show a world full of respect for women, a world that is egalitarian. The rumours have made Samin people vulnerable and marginalised. Those who were mostly insulted by the rumours were women. This article explores the history of Samin society and its social political context to reveal the reasons behind the rumours.
\end{abstract}

Key Words: Samin, marriage, rumours, 'virginity test', 'stray marriages'

\begin{abstract}
Abstrak
Artikel berjudul 'Rumours and Realities of marriage Practices in Contemporary Samin Society' yang dipublikasikan di Humaniora (Juni 2010) telah mengkonfirmasi bahwa mitosmitos mengenai praktek-praktek 'tes keperawanan' dan dan 'kawin umbaran' tidak terbukti kebenarannya. Sebaliknya komuniti Samin melalui sistem perkawinannya menunjukkan dunia yang penuh penghargaan terhadap perempuan, sebuah dunia yang egaliter. Rumorrumor tersebut membuat orang Samin menjadi rawan dan terpinggirkan. Mereka yang paling terluka akibat rumor tersebut adalah kaum perempuan. Artikel ini berupaya memahami sejarah masyarakat Samin dalam konteks sosial politik untuk membuka alasan-alasan dibalik munculnya rumor yang ada.
\end{abstract}

Kata Kunci : Samin, perkawinan, rumor, 'tes keperawanan', 'kawin umbaran'

\section{INTRODUCTION}

There is a big question mark when it is realised that the rumours about the "virginity tests' and the 'stray marriages' in the Samin community are discredited. By contrast, the Samin Klopoduwur marriage practice system seems to show a high level of respect for women. According to Engels ${ }^{1}$, in the past (pre-industrial times), most families to the form of 'primitive matriarchies', in which women had a higher status than men. There was no segregation between the roles of men and women in public and domestic areas. However, patriarchy took over when the societies became more complex and modern. Regarding the 'primitive matriarchy', Samin communities have the same characteristic of pre-industrial families. This is because they are a simple society which rejects 'modern jobs'. So they choose work as farmers and shepherds which is what they learnt from their ancestors. That may be why there is an egalitarian spirit between men and women. Similar systems can be

${ }^{1}$ D. Morgan, Social Theory and The Family, London, 1978, p. 139. 
found in the Nayars of Kerala and the Minangkabau of Sumatra in the past, which showed sexual indiscriminacy in the family and had an egalitarian group-quality around economic and marriage arrangements. ${ }^{2}$

The rumours about the 'virginity tests' and the 'stray marriages' have made Samin people vulnerable and marginalised. Those who were mostly insulted by the rumours were women. The rumours seem to reflect the ideas and values of a patriarchal culture in which women are subordinated to men. Simone de Beauvoir ${ }^{3}$ said that sexuality plays a significant role in human life. Men who describe themselves as 'the-self' and women as 'others' feel threatened by women and the way for those men to feel secure is by oppressing women. They do this by creating symbols and myths so that women tend to become subordinate, institutionalised, and see this as a destiny to which they are born ${ }^{4}$. Judith Butler ${ }^{5}$ argues that perceptions of a woman's body are created, constructed and imposed through cultural norms. A woman has little choice relating to her body because the cultural norms govern her and her body. This explains why the rumours and myths degrade the women in Samin community.

To reveal the reasons behind the rumours, it is necessary to look at and to understand the social and political context surrounding Samin. Understanding the history of Samin society will help in answering why the rumours exist. My research shows that the rumours result from cultural collisions and political interests, which try to exploit, to defeat, and to diminish this community.

\section{THE HISTORY OF SAMIN MOVEMENT}

In 1830 when the Dutch Government enforced the Cultuurstelsel ('Cultivation System'), it caused suffering in rural Java owing to a lack of rice. ${ }^{6}$ The 'Cultivation System' required people in rural Java to plant special plants such as coffee, sugar cane and indigo (products that were in high demand in the European market). Ironically, at the same time, the peasants also still had to pay tax to the Dutch government. ${ }^{7}$ This explains why some members of the elite classes in rural Java did not want to cooperate with the Dutch government. One such person was Soerantiko Samin. Ploso Kediren was a temporary hiding place from the Dutch government. This place was chosen by Soerantiko due to its location which was ledok (a valley) surrounded by teakwood forest. ${ }^{8}$

In Ploso Kediren, Soerantiko taught his followers to struggle against Dutch colonialism by using political non-cooperation without violence and by telling the truth. This method was similar to, but preceded, that of Gandhi's 'Ahimsa' (non-violence) and 'Satyagraha' (non-cooperation) in India. ${ }^{9}$ Besides refusing to pay tax, Soerantiko and his followers also resisted repairing roads, compulsory patrolling at night and using money. Soerantiko's decision to use non-violent methods was a new model of resistance against the Dutch colonial government. This can be compared with the Pangeran (prince) Dipanegara's

\footnotetext{
${ }^{2}$ Kathleen Gough, 'The Origin of the Family', in Toward Anthropology of Women, ed. Rayna R. Reiter, New York, 1975, pp. 73-74.

${ }^{3}$ Simone de Beauvoir, The Second Sex, New York, 1989, pp. 77-78.

${ }^{4}$ R. Connell, Gender, Cambridge, 2002, p. 30.

5 Judith Butler, Bodies That Matter, New York, 1993, p. 3.

${ }^{6}$ Robert van Niel, Java Under the Cultivation System, Leiden, 1992, p. 208; Robert van Niel, 'The Effect of Export Cultivations in Nineteenth-Century Java', Modern Asian Studies, vol. 15, no. 1, 1981, p. 57.

${ }^{7}$ Ibid., p. 10.

${ }^{8}$ Abdullah. 'Anak orang Samin', in Perjalanan Anak Bangsa: Asuhan dan Sosialisasi dalam Pengungkapan Diri, eds. Aswab Mahasin, Ismed Natsir dan Thamrin Hamdan, Jakarta, 1982, p. 307.

${ }^{9}$ Erik H. Erikson, Gandhi's Truth, New York, 1969, pp. 373-385; George Woodcock, Gandhi, London, 1974, pp. 8-11; Geoffrey Ashe, Gandhi: A Study in Revolution, London, 1968, pp. 99-103; Dennis Dalton, Mahatma Gandhi: Nonviolent Power in Action, New York, 1993, pp. 45-47.
} 
rebellion against Dutch colonialism (the 'Java War'), which lasted from 1825 until 1830. Although Pangeran Dipanegara was supported by many in the Javanese elite as well as by ordinary people, his struggle was still defeated by the colonial government. ${ }^{10}$

According to Soerantiko money was easy for the Dutch government to make, while producing food required the peasants to work hard. With this logic as his starting point, Soerantiko preferred to 'barter' rather than use money. He also taught his followers to survive by producing their own food, as it was the result of their own hard work. They concealed their property such as cattle in forests and buried their rice and other agricultural produce under their houses, so that the Dutch government could not find it. The resistance against using money is also similar to Gandhi's concept of 'Swadhesi'. ${ }^{11}$ However, the difference was that Gandhi was a scholar, whilst Soerantiko Samin only knew the politics of noncooperation from his own reflections during his resistance.

Soerantiko Samin also argued for equality among people. The basis of his conception of equality was the idea that all humans were created equal in the eyes of God. According to this logic, there should be no classes in society. Following these ideas, Soerantiko used Ngoko Javanese ${ }^{12}$ to speak with the Dutch government and the Javanese elite. ${ }^{13}$ This is because he believed that the elite classes in Java, such as kings (e.g. The Sultan of Yogyakarta and The Sunan of Surakarta), regents, wedana (head of district), lurah (head of village), and all other levels of the Javanese aristocracy were the lackeys of the colonial government. The elite classes only knew pleasure in their palaces because of Dutch money. They did not care about the fate of poor peasants in rural Java.

Another key concept of the Soerantiko's thought is the idea that all nature was made by God and in essence is the property of all people. Samin people say, 'Lemah pada duwe, banyu pada duwe, kayu pada duwe' (Land, water and wood are the property of all). The idea that nature is the property of all people implied that there was no reason why tax should be paid. ${ }^{14}$ Based on this belief, they rejected the monopoly system, which was forced on them by the colonial government and defended their access to forests. ${ }^{15}$ In this context, Saminists objected to restrictions on access to forests. ${ }^{16}$ This resistance was also influenced by their belief that tax was not collected for the kings of Java, but for the Dutch government. Furthermore, they were sure that tax was not used to improve the people's welfare but made them poorer. ${ }^{17}$

${ }^{10}$ P.B.R. Carey, Babad Dipanagara: An Account of the Outbreak of the Java War (1825-1830), Kuala Lumpur, 1981, p. XXXIX.

${ }^{11}$ Dalton, Mahatma Gandhi, p. 46.

${ }^{12}$ Ngoko Javanese is the lower form of Javanese language (the impolite form). In Java, language can be classified into three basic forms: Ngoko (lower), Krama (higher) and Madya (middle). Ngoko is informal speech, used between friends and close relatives or by persons of higher status to persons of lower status. Krama is the polite and formal style, used by persons of lower status to persons of higher status, such as youngsters to elder people or subordinates to bosses. Madya is the intermediary form between ngoko and krama.

${ }^{13}$ Amrih Widodo, 'Samin in the New Order: The Politics of Encounter and Isolation', in Imagining Indonesia: Cultural Politics and Political Culture, eds. Jim Schiller \& Barbara Martin-Schiller, Ohio, 1997, p. 264.

${ }^{14}$ Harry J. Benda \& Lance Castles, 'The Samin Movement', in Bijdragen tot de Taal-, Land- en Volkenkunde 125, no. 2, Leiden, 1969, p. 223.

${ }^{15}$ James C. Scott, 'Protest and profanation: Agrarian revolt and the little tradition (Part II)', Theory and Society, vol. 4, no. 2, Summer, 1997, p. 216.

${ }^{16}$ Peter Boomgaard, 'Colonial forest policy in Java in transition 1865-1916', in The Late Colonial State in Indonesia: Political and economic foundations of the Netherlands Indies 1880-1942, ed. Robert Cribb, Leiden, 1994, p. 134.

${ }^{17}$ According to King, the cause of the Samin movement was not solely due to economic factors, but was also influenced by other factors, e.g. social and political factors (Victor T. King, 'Some observations on the Samin movement of North-Central Java: Suggestions for the theoretical analysis of the dynamics of rural unrest', Bijdragen tot de Taal-, Land- en Volkenkunde 129, no. 4, Leiden, 1973, p. 463; Victor T. King, 'Status, economic determinism and monocausality: more on the Samin', Bijdragen tot de Taal-, Land- en Volkenkunde 
Soerantiko's courage in refusing to pay tax made his standard of living better because he had three $b_{a u}{ }^{18}$ of sawah (wet field rice), one bau of ladang (un-irrigated agricultural field) and six cows. ${ }^{19}$ Knowing this, people found a charismatic leader in Soerantiko Samin. They thought that what Soerantiko Samin did was right and it was a means of getting a better life during the Dutch colonial era. At that time, a peasant had to pay a tax to the value of three cows per year. ${ }^{20}$ Moreover, after rumours that Soerantiko Samin had received wahyu (blessing from God) became widespread the number of his followers dramatically increased. During his struggles against the Dutch government, he and his followers hid in the middle of forest to avoid taxes and officials, and the people listened to his sermons about how to be a good person, which was then popularised as Agama Adam (the 'Religion of Adam'). Interestingly, Samin wives and widows stayed in their houses and dared to argue for refusing to pay taxes with the government's tax officers. ${ }^{21}$

Benda and Castles mention that in 1903 Resident Rembang reported that there were 772 Samin people who were spread amongst 34 villages in Blora and Bojonegoro. ${ }^{22}$ This number increased dramatically to 5,000 people in $1907 .{ }^{23}$ The Samin movement reached a climax when on 8 November 1907, without Soerantiko's knowledge, his followers declared him 'The King of Java'. However, forty days after this celebration nine Samin people were arrested by Ndoro Seten (an assistant district head), Raden Pranolo. ${ }^{24}$ They were then jailed in Blora, Rembang, and Batavia before being exiled to Padang, Bengkulu and Manado. Soerantiko Samin was exiled in Padang, however, some people believed that he was actually sent to Sawahlunto, Sumatra. ${ }^{25} \mathrm{He}$ died in 1914.26

\section{THE SAMIN COMMUNITY IN KLOPODUWUR TODAY}

The location for this study, Dukuh Karang Pace, lies about one kilometre south of Klopoduwur village and seven kilometres south of Blora. Dukuh Karang Pace is only 6 hectares in area and consists of three dwellings or enclaves, each enclave comprising 7-8 houses. The total number of houses in Karang Pace is 22 and each enclave has a familial relationship. Each enclave has access to the Blora-Randublatung Street ( \pm 200 metre) but only a pathway through wet rice fields connects the enclaves. Samin people refer to their houses being of the Bekuk Lulang (bark bent up) model, using teak wood bark as the main building material. The soil in Karang Pace is dry and contains much lime stone. This area is surrounded by teak-wood forest and there are no water sources which means there are often water shortages.

Karang Pace now has a population of 122 people who are divided into 31 households. Almost all people in Karang Pace work as farmers and shepherds. Some of them also collect

133, no. 2/3, Leiden, 1973, pp. 350-351). On the other hand, Korver argues that economic considerations were the essential factor which explained the movement (A. Pieter E. Korver, 'The Samin movement and millenarism', Bijdragen tot de Taal-, Land- en Volkenkunde 132, no. 2/3, Leiden, 1976, p. 256).

${ }^{18}$ One bau is equivalent to $7,096.49 \mathrm{~m}^{2}$.

${ }^{19}$ Ibid., p. 464.

${ }^{20}$ Interview with Lurah Ploso Kediren, 8 January 2009.

${ }^{21}$ Interview with Mbah Lasiyo (Engkrek's grand son), 12 January 2009. At the time, there was a Javanese belief that someday a messiah referred to as the Ratu Adil (Just King) would come to save people in Java and would bring prosperity to all (Justus M. van der Kroef, 'The Messiah in Indonesia and Melanesia', The Scientific Monthly, vol. 75, no. 3, Sep., 1952, p. 307). This belief was strong in the minds of Javanese people, especially those who lived in rural Java.

${ }^{22}$ Benda \& Castles, 'The Samin Movement', p. 211.

${ }^{23}$ Setya Yuwana Sudikan, Tradisi dari Blora, Semarang, 1996, pp. 14-15.

${ }^{24}$ Those are Soerantiko Samin, Soredjo, Singotirto, Kartogolo, Ronodikromo, Soerjani, Surowiryo, Tokromo and Kromonggolo.

${ }^{25}$ Interview with Mbah Sampan, 15 January 2009.

${ }^{26}$ King, 'Some observations', p. 459. 
firewood, teakwood leaves, and makes charcoal. They call a cow as rojo koyo (the most valuable kind of property). Therefore, some of them still live with their cows in the same house.

Most of the elderly are illiterate, whilst their children usually do not get past junior high school. They believe that if people have higher education, it is more likely they will become civil servants. They consider this job as the job of a lackey of the Indonesian government, which is no different from the previous Dutch colonial governments. They also avoid becoming traders due to their belief that traders often lie to others to make a profit.

Now they still speak in Ngoko Javanese and use kerata basa, which means a speech skill that gives a second meaning to some words, only known by this community and which is confusing to others. This skill made it difficult for the Dutch government in the past to understand the language of this community and so they failed to negotiate with them. For example, sembahyang means praying, but they use sembahyang to mean mesem tambah nggrayang (after smiling, then you touch), giving sembahyang 'double extendre meaning'. Likewise, bumi means earth, but they use bumi to mean mlebune diemi-emi (penetration should be done carefully), and wali means saint, but they use wali to mean sing disuwali (the thing you cover with cloth, i.e. penis). ${ }^{27}$

\section{BELIEF SYSTEM}

Samin people believe in the existence of God, who they call Gusti (Lord), Sing Gawe Urip (A creator of living), or Pangeran (Prince/Lord). They believe that each living creature has a spirit. This is also the case for every shrine, which has a danyang (tutelary spirit). They also believe in the existence of 'sedulur papat limo pancer ${ }^{28}$ and karma (the law of cause and effect in every action). In their view, there is process of reincarnation after salin sandangan (death). People can be reborn as humans if they behave well in their previous life. Conversely, they can be nitis (reborn) as animals if they behave badly. Those who have a very good attitude and behaviour will reach moksa (redemption). This is why many people from Bali consider Samin people to be the followers of Hindu Jawa (Javanese Hinduism).

The term of Agama Adam is taken from their teaching 'Agama niku gaman, Adam pangucape, man gaman lanang' (agama [religion] is as a man's weapon [penis] and Adam [Adam=dam=damel=job] means sikep rabi [coitus]). In Agama Adam, the meaning of life is making the effort to reach manunggaling kawulo Gusti (unity with the divine). This can be seen from the expression, 'Ing sajroning agama ana rasa, rasa sajatine rasa, rasa sajatine wujud banyu' (in deep religion there is a feeling, a true feeling, this feeling is like water). To achieve this stage a human must make an effort to understand sangkan paraning dumadi (the essence of life; from where they come and to where they go). Samin Soerantiko explains this by giving the analogy of rangka umanjing curiga (when keris or the Javanese dagger is entering its sheath). This means that that the keris cannot be separated from its sheath so it is like a human being and God. It is the task for a human to seek to know God so that they can unite with God through good behaviours such as mamayu hayuning bawono (to preserve the beauty of the world or to improve the welfare of the world).

The essence of Agama Adam is manifested in several laws which have to be kept by the Samin. First, 'Aja dengki srei, tukar padu, dahpen kemeren, kutil jumput, mbedog colong' (Samin people are forbidden to be jealous, have malevolent feelings or to steal from others). Secondly, 'Pangucap saka lima bundhelane ana pitu lan pengucap saka sanga budhelane ana pitu' (all conversations have to be based on honesty, facts, without being exaggerated or

\footnotetext{
${ }^{27}$ Widodo, 'Samin in the New Order', p. 285.

28 Sedulur papat limo pancer (four siblings, the fifth is central). Some people mention as kiblat papat limo tengah. It refers to four spirits which protect human beings from North, East, South and West. The fifth is guru sejati (the spirit of mind) which always guides humans.
} 
understated by manipulation). This means that people have to protect their mouths from improper words, which can insult others. Thirdly, 'Lakonana sabar trokal, sabare dielingeling, trokale dilakoni'. This means that Samin people are expected to be patient, remember their patience, and behave well. According to Soerantiko, all teachings can be realised by people if they practice semadi (meditation).

In relation to marriage practices, Samin people believe that all activities in the world have a form, which can be divided, into two parts: wong (human) and sandang pangan (food and clothes). For wong, there were two types that is lanang (male) and wedok (female). In their activities, they have two aims of life: tatane wong that is to produce wong through sikep rabi (sex) and toto nggaoto that is to produce food and clothing by cultivating their land. The two aims influence their world view. The idea of two ways are formulated in the expression 'Jen bengi tatane wong, jen rino toto nggaoto' (Night is for having sexual intercourse, day is for working). Therefore, wong sikep's life follows Adam, that is processing their land in the daytime and doing tatane wong at night. In addition, there are two wong: Wong jowo (literally 'a Javanese', i.e. a real Javanese person) who is honest, kind, and never lies, and wong jawal who is crazy and evil. Thus, wong sikep or wong peniten has to follow Agama Adam to become wong jowo.

Based on the outline above, it could be concluded that Agama Adam is syncretised from Hinduism, Buddhism, and animism ${ }^{29}$ as shown by the terms such as Karma, Moksa, Nitis, Danyang, and Sedulur papat limo pancer. In the context of marriage, Samin people believe that marriage is a way to live well. Marriage is important for Samin people and is wrapped in special stages that only can be understood by members of the Samin community.

\section{ISLAM AND THE 'RELIGION OF ADAM'}

Islam came to Indonesia in the 14th century and has since become widespread in almost all areas including Java. ${ }^{30}$ This religion entered Java and developed quickly in Demak, on the north coast of Central Java. In 1511, after attacking Majapahit, Demak became the first Islamic Sultanate in Java. Many followers of Hinduism-Buddhism changed their religion to Islam. ${ }^{31}$ However, some of them moved to Bali, Lombok and rural Java to avoid Islamic influences and refused to embrace Islam. ${ }^{32}$ In the beginning, they were interested in Islam. However, after 'Gerakan Puritanisasi Islam' (Islamic purifying movement) happened in Indonesia, Islam did not tolerate the local culture such as sesajen (ritual offerings) and other Hindu or Buddhist traditions. ${ }^{33}$ This is because the 'purifying movement' believes that sesajen is syirik (polytheistic). They tried to introduce a form of Islam from Mecca, which did not tolerate any bid'ah (heresy). That is why at that time many Hindu-Buddhists rejected Islam. This 'purifying movement' held to a strict interpretation of the Qur'an (Koran) and Hadiths $^{34}$. It claimed that the only people who will go to heaven or paradise are Muslims.

\footnotetext{
${ }^{29}$ Animism is an idea that souls or spirits exist not only in humans and animals but also in plants, rocks, and natural phenomena such as thunder, geographic features such as mountains or river, or other entities of the natural environment.

${ }^{30}$ Franz Magnis-Suseno, Javanese Ethics and World-View: The Javanese Idea of the Good Life, Jakarta, 1997, p. 34.

${ }^{31}$ Ibid., p. 36.

${ }^{32}$ Mark R. Woodward, Islam in Java: Normative Piety and Mysticism in the Sultanate of Yogyakarta, Tucson, 1989, p. 8; N J. Smith-Hefner, 'Pembaron: An East Javanese Rite of Priestly Rebirth', Journal of Southeast Asian Studies, vol. 23, no. 2, Sep., 1992. p. 237; Adi Putranto, 'Pandangan Masyarakat Gunung Kidul Terhadap Pelarian Majapahit Sebagai Leluhurnya', Humaniora, vol. xv, no. 2, 2003, pp. 225-228.

33 Jusuf Wanandi, 'Islam in Indonesia: Its History, Development and Future Challenges', Asia-Pacific Review, vol. 9, no. 2, 2002, pp. 105-106.

${ }^{34}$ Hadith refers to traditional collection of stories relating words or deeds of Muhammad the chief source of guidance for understanding religious questions.
} 
They called the followers of other religions kafirs (infidels) who will go to hell. They insisted that the infidels or followers of other religions must be Islamised or minimised.

However, Agama Adam challenges the domination of Islam. Saminists believe that all religions are good and that the most important thing is not what people's religion is but whether they do good things in daily living. As they say, 'Agama Islam ya duwe, agama Katholik ya duwe, Budha ya duwe, wong kabeh iku apek' (Islam I have, Christianity I have, Buddhism I have, because all religions are good). The fear of Agama Adam expansion made Moslems vigorous in dakwah (missionary endeavours). They built many masjids (mosques) and mushollas $^{35}$ in Samin communities in an attempt to islamise them.

Clifford Geertz's study about the religion of Java divides that religion into three categories: Santri, Abangan and Priyayi. ${ }^{36}$ The Santri are those who believe in Islam. They generally are rich farmers and merchants. Abangan are those who follow HinduismBuddhism, which has been influenced by animism. Abangan is marked by a visionary spirit that someday the Ratu Adil (Just King) will come and bring prosperity to them, as in Majapahit era. Most Abangan farmers are very poor. Priyayi are the Javanese aristocrats who occupy positions in the government and they are acknowledged as an elite class in Java. The position of this group is half way between the Santri and Abangan.

The conflict between Abangan and Santri can be seen in the myth of Sheikh Siti Jenar (Sheikh Lemah Abang) who opposed the domination of wali songo (the nine Islamic saints) in the Sultanate of Demak. ${ }^{37}$ Sheikh Siti Jenar was judged murtad (apostate of Islam) because he had never sholat (prayed) in the masjid or musholla and taught manunggaling kawulo Gusti (unity with the divine). Due to his teachings which endangered Islam and the Sultanate of Demak, he was sentenced to capital punishment by wali songo and Raden Patah (Sultan of Demak). ${ }^{38}$ The conflict between Abangan and Santri is also illustrated by two suluks (a form of Javanese traditional mystical literature), Suluk Darmaghandul and Suluk Gatholoco. ${ }^{39}$ In these suluks, which were published in the 1800s, Ki Kalamwadi, the author, criticised wali songo and Muslims who were so arrogant about their saints, who burnt all Buddhist books, and destroyed Javanese culture. ${ }^{40}$ The essence of Agama Adam also can be found in these suluk:

Table 1: The essence of Agama Adam in Suluk

\begin{tabular}{|l|l|}
\hline Javanese & Meaning \\
\hline \hline Djenenge lanang, damele rabi. & 'It is the male's role to marry. \\
Tata-tata wedokjanji demen. & $\begin{array}{l}\text { I am faithful to pledges in respect to } \\
\text { women. } \\
\text { In the name of the Prophet of Adam who } \\
\text { shall exist till the end of the ages. } \\
\text { Sing kulo niteni tatane sikep rabi. }\end{array}$ \\
$\begin{array}{l}\text { I will remember the regulation of the } \\
\text { Saldege wekasan. }\end{array}$
\end{tabular}

${ }^{35}$ Musholla is small building or room set aside in a public place for performance of religious duties (small mosque).

${ }^{36}$ Clifford Geertz, The Religion of Java, Chicago, 1976, pp. 5-6.

${ }^{37}$ Hermanu Joebagio,'Religious Splinter Movement from Historical Perspective', Jurnal Millah (Jurnal Studi Agama), vol. 7, no. 2, 2008, pp. 5-6.

${ }^{38}$ Julia Day Howell, 'Sufism and the Indonesian Islamic Revival', The Journal of Asian Studies, vol. 60, no. 3, Aug., 2001, p. 707.

${ }^{39}$ Putranto, 'Pandangan', pp. 230-231.

${ }^{40}$ Benedict Anderson, 'The Suluk Gațoloco: Part One', Indonesia, vol. 32, Oct., 1981, pp. 114-115. 
\begin{tabular}{|l|l|} 
Wong Sikep weruh teke dewe. & $\begin{array}{l}\text { conjugal household. } \\
\text { I (Wong Sikep) embrace my wife only.' }\end{array}$ \\
\hline
\end{tabular}

In 1965, the 'Old Order' regime of Soekarno was deposed and replaced by the 'New Order' regime of Soeharto. This year can be considered as the triumph of Islam over Abangan. Santri and the military combined to outlaw communists. Due to the similarity between communism and the communalism of the Samin, Samin people were judged communists. Many people were killed without trial. Bakker ${ }^{41}$, in his study reveals how the New Order government built special institutions called 'Pilot Projek Pembinaan Mental Agama' (P3A), in order to give the Muslim people specific guidance. Because of this program, many Samin people were forced into kawin massal (mass re-marriage) in Islam. Those who refused this program would be in trouble with the police. In this context, Saminists were sentenced twice by accusing them as being communists and publicly humiliating them in public. Based on this conflict, it is possibly that Santri contributes in creating or developing the rumours about the 'virginity test' and the 'stray marriages' in Samin society.

\section{JAVANESE CULTURE: THE DOMINANT CULTURE}

The research that was carried out by Edward M. Bruner ${ }^{42}$ about dominant culture can be used to examine the collision between Samin and Javanese cultures. Javanese society has great power to influence people from outside in the use Javanese language and traditions. However, Samin communities as Javanese in some cases use different language and traditions, especially in marriage and funerals. Obviously, this community is considered deviant owing to culture differences. It appears that Samin has challenged Javanese culture ${ }^{43}$ and must be punished. This can be shown by calling Samin as Suku Samin (Samin ethnic group), but not Suku Jawa (not Javanese ethnic group). This means that Samin are not fully Javanese and have been expelled from Suku Jawa. This 'betrayal' is the price that has to be paid because of their differences. This is the consequence of challenging the dominant Javanese culture and so Samin have been marginalised by the dominant culture.

An important aspect, which contributes to the marginalisation of the Samin community, is the egalitarian spirit of this community. Javanese has a hierarchy system for referring to status in their society. It has three hierarchal classifications: Ngoko, Madya, and Krama. In using Javanese, the lower class cannot use Ngoko Javanese to elite classes. This would be interpreted as socially inappropriate. In actual fact, Samin people use Ngoko Javanese to everybody, without acknowledging hierarchy. This egalitarian spirit can be seen from the dialogue between Saminist and Priyayi:

Table 2: Dialog between Saminist and Priyayi I

\begin{tabular}{|l|l|}
\hline Javanese & Meaning \\
\hline \hline $\begin{array}{l}\text { Priyayi: 'Kenopo anggonmu ngomong } \\
\text { ora biso boso? }\end{array}$ & $\begin{array}{l}\text { Priyayi: 'Why are you so impolite in your } \\
\text { speech?' (Using Ngoko). }\end{array}$ \\
Saminist: 'Nek sing sekolahe dhuwur & \begin{tabular}{l} 
Saminist: 'If people who have a high \\
\hline
\end{tabular}
\end{tabular}

\footnotetext{
${ }^{41}$ D. Bakker, 'The Struggle for the Future some Significant Aspects of Contemporary Islam in Indonesia, The Muslim World, vol. 62, no. 2, 1972, pp. 126-136.

42 Edward M. Bruner, 'The Expression of Ethnicity in Indonesia', in Urban Ethnicity, ed. Abner Cohen, London, 1974, pp. 275-276.

${ }^{43}$ Benda \& Castles, 'The Samin Movement', p. 210.
} 
wae ora biso boso, opo maneh sing ora sekolah.' education cannot be polite in their speech, how can they expect people who do not have an education at all, like me, to be polite?'

(Also using Ngoko).

The uniqueness of Samin language can be seen from the conversation between Priyayi and Saminist: ${ }^{4}$

Table 3: Dialog between Saminist and Priyayi II

\begin{tabular}{|c|c|}
\hline Javanese & Meaning \\
\hline Priyayi: 'Jenengmu sopo?' & Priyayi: 'What is your name (jeneng)?' \\
\hline Saminist: 'Lanang.' & Saminist: 'Male.' \\
\hline $\begin{array}{l}\text { Priyayi: 'Dudu kuwi sing tak karepake. } \\
\text { Contone, Pak Lurah kuwi jenenge } \\
\text { Karyodiharjo; Bapak Guru Kemantren } \\
\text { kuwi jenenge Sukardi. Jenengmu sopo?' }\end{array}$ & $\begin{array}{l}\text { Priyayi: 'That is not what I mean. As an } \\
\text { example, the head of village has a name } \\
\text { Karyodiharjo; the teacher from } \\
\text { Kemantren has a name Sukardi. What is } \\
\text { your name (jeneng)?' }\end{array}$ \\
\hline $\begin{array}{l}\text { Saminist: 'Kuwi dudu jeneng, nanging } \\
\text { pangaran.' }\end{array}$ & $\begin{array}{l}\text { Saminist: 'That is not a name (jeneng), } \\
\text { it is just what someone's called } \\
\text { (pangaran).' }\end{array}$ \\
\hline Priyayi: 'Pangaranmu sopo?' & $\begin{array}{l}\text { Priyayi: 'What are you called } \\
\text { (pangaran)?' }\end{array}$ \\
\hline Saminist: 'Suradi.' & Saminist: 'Suradi' \\
\hline Priyayi: 'Penggaweanmu opo?' & $\begin{array}{l}\text { Priyayi: 'What is your job } \\
\text { (penggawean)?' }\end{array}$ \\
\hline Saminist: 'Laki.' & Saminist: 'Coitus.' \\
\hline $\begin{array}{l}\text { Priyayi: 'Dudu kuwi. Contone, } \\
\text { penggaweane Pak karyodiharjo kuwi dadi } \\
\text { lurah; penggaweane Pak Sukardi kuwi } \\
\text { dadi guru. Penggaweanmu opo?' }\end{array}$ & $\begin{array}{l}\text { Priyayi: 'That is not what I mean. As an } \\
\text { example, Karyodiharjo has a job as the } \\
\text { head of village; Sukardi has a job as a } \\
\text { teacher. What is your job } \\
\text { (penggawean)?' }\end{array}$ \\
\hline $\begin{array}{l}\text { Saminist: 'Kuwi dudu penggawean, } \\
\text { nanging penggautan. Penggautanku tani.' }\end{array}$ & $\begin{array}{l}\text { Saminist: 'That is not a job } \\
\text { (penggawean), but it is just work } \\
\text { (penggautan). My work is farming.' }\end{array}$ \\
\hline
\end{tabular}

Another aspect, which also contributes to marginalising the Samin community, is their desire to challenge the patriarchal culture in Java. In Java, a man has a higher status than a woman does. The men can take part in public life, which is more prestigious, while the women cannot do so. The head of household is always a man. A woman has a close association with dapur, sumur, and kasur (kitchen/cooking, well/washing and bed/having coitus). This strong patriarchal culture can be shown by the practice of polygamy in Java. A man can marry more than one woman. The early Indonesian feminist Kartini, who was

44 Darmo Subekti, Tradisi Lisan Pergerakan Samin: Legitimasi Arus Bawah Menentang Penjajah, Paper Unpublished, Blora, 1999, pp. 9-10. 
actively struggling for gender equality in Jepara, Central Java, is a good example. Even though she had a good education, a woman had to be silent when her husband practiced polygamy. This is different from Saminists who have more respect for women. Women in Samin can participate in domestic and public spheres like men; and a man may not practice polygamy because this will denigrate women. Based on these facts, it is possible that ordinary Javanese contribute to creating or developing the rumours about the 'virginity tests' and the 'stray marriages' to marginalise the Samin.

\section{THE SAMIN GOGOL}

Samin people are very honest and simple in their lives. This is shown in their traditions, such as in marriage. However, these traditions are vulnerable to exploitation by outsiders. Many people often come to this community and pretend to be Samin (nyamin). ${ }^{45}$ This is called Samin Gogol. They pretend to be Samin to obtain benefits from this community. For example, they can marry a Samin woman just for fun and then leave her without any responsibility because there is no marriage certificate in their marriage system. Samin Gogol views the Samin marriage system as an easy target for manipulation. This is because they do not really understand Samin principals and so they contribute to destroying the adat in the Samin community.

In Dangir's testimony, it is stated that Dangir was a Samin who studied his Saminism with an old man in his village (Kek Soeroleksono). ${ }^{46}$ However, this can be questioned because Samin people rarely share their beliefs with outsiders, such as government officers. However, Dangir did. This means that Dangir was probably not a 'real Samin' (Samin Gogol). As a proof, Shiraisi says that after giving testimony, Dangir left his Saminism. ${ }^{47}$ This is odd when Saminists always keep Agama Adam, but he easily changed his belief. The teacher who taught in his village also needs to be questioned. This is because his lesson about 'Stray Marriages' have never existed in Agama Adam. Based on this fact, the teacher who taught Dangir in that time must have been Samin Gogol. This means that his lessons to Dangir's and his relatives were 'fake teachings' and influenced by the patriarchal culture. This influence can be detected from a gender bias, which construed women as tools for men's pleasure. That is why its teachings different from the original.

What Samin Gogol does is selfish. ${ }^{48}$ They benefit not only from not paying tax like other 'real Saminists', but also exploit the Samin marriage system. However, the Samin community have anticipated this by having strict selection processes in marriage. Besides implementing their social controls to protect them from the Samin Gogol, they also strongly develop their communication between Samin communities so that they can recognise who are Samin Gogols and who are the real Saminists. Many 'free riders' (Samin Gogols) in the marriage practice also contribute to the destroying of Samin adat. It seems possible then that the Samin Gogol also possibly take part in creating or developing the rumours about the 'virginity tests' and the 'stray marriages' in Samin society.

\section{DIVIDE ET IMPERA}

It cannot be denied that the passive resistance (lijdelijk verset) of Saminists disturbed the Dutch colonial government. The movement spread quickly and jeopardised Dutch policies in forest management and tax payment. The non-violence and closed quality of the movement made it difficult for the Dutch to defeat Samin. Their language, which was

\footnotetext{
${ }^{45}$ Samin people also called them as 'Samin-Saminan' or 'Samin Pamrih' (Samin who are opportunists).

46 Takashi Shiraishi, 'Dangir's testimony: Saminism reconsidered', Indonesia, vol. 50, Oct., 1990, p. 98.

${ }^{47}$ Ibid., p. 120.

48 Ghufron, Pengaruh Kepemimpinan Kepala Desa Terhadap Perilaku Keagamaan Masyarakat keturunan Samin di Desa Kemantren Kecamatan Kedungtuban, Kabupaten Blora, Semarang, 1998, p.28.
} 
difficult to understand, also contributed to making negotiations fail. ${ }^{49}$ Refusing to pay taxes, Samin people also refused to acknowledge state forests, refused to pay marriage costs to the state and refused to use Dutch money. Obviously, this movement challenged the Dutch colonial government and influenced the social, economical and political stability of Java. ${ }^{50}$

The conflict between Priyayi, Abangan and Santri helped the Dutch government to eliminate the Samin movement. The Dutch government used the same strategy that they used to defeat Minangkabau and Aceh: divide and rule (Divide et Impera). Divide et Impera was a common Dutch strategy due to the fact that they were chronically short of manpower and other resources required to guarantee the colonial order. They split power in society between religious people and aristocrats, and supported one of them.

To overcome the Samin movement, the Dutch government used a cunning method to create a conflict between ordinary Javanese people and the Saminists. They made aristocrats into bureaucrats in their administration. ${ }^{51}$ As a result, the Dutch had transformed the vertical conflict between government and Saminists to a horizontal conflict between Priyayi and Saminists (Javanese versus 'Javanese'). It also seems that the Dutch government preferred to support orthodox Islam as a majority religion in Java, which had shown little resistance, rather than Abangan religion (Agama Adam), which tended to oppose government policy. This can be seen from their support of Islam and its traditions by using mainstream Islam in the shaping of laws (e.g. marriage law). ${ }^{52}$

In the context of Samin movement, the Dutch created negative stereotypes of this community, calling them tani bento (mad peasants). ${ }^{53}$ It is possible that the Dutch colonial government also contributed to the creation of the rumours about the 'virginity tests' and 'stray marriages' as part of their strategy to split the power of the people of Java.

\section{THE POLITICS OF JAVANESE ELITE CLASSES}

The Samin movement was a threat to the Priyayi who worked for the Dutch government. This is because Samin people called them as antek londo (the lackey of the Dutch) and did not obey the law, such as paying tax to the government. As a result, the Priyayi who failed to collect taxes would risk their position and the Dutch government would replace them with others. They often oppressed Samin people and used violence such as beating, sending them to jail and seizing their property without their consent. They also manipulated people and used them as a tool for bargaining with the Dutch. ${ }^{54}$ This was possible because the Priyayi were familiar with the language of the Samin, while many reports had to be written in Dutch or Malay. Michael Adas argues that many ordinary people probably trusted the Samin movement over the Priyayi. When Soerantiko appeared and taught resistance to the Dutch and their policies, many moved away from the Priyayi towards Soerantiko. Consequently, Soerantiko became new patron in rural Javanese patron-client relationships. ${ }^{55}$

Another reason which explains why the Priyayi view Samin as a threat is the way Samin people speak and think, which often makes them feel embarrassed and denigrated by Samin. This is because by answering back to what Priyayi said, the Samin challenged the

\footnotetext{
49 Masato Fukushima, 'The Closed Language: The Samin Movement and Its Philosophy of Language', Southeast Asian Studies, vol. 24, no. 4, 1987, pp. 423-424.

${ }^{50}$ Kroef, 'The Messiah', p. 162.

${ }^{51}$ Benda \& Castles, 'The Samin Movement', p. 234.

52 Ibid.

${ }^{53}$ Shiraishi, 'Dangir's testimony', p. 97.

${ }^{54}$ Ibid., p. 105.

${ }^{55}$ Michael Adas, 'From avoidance to confrontation: Peasant protest in precolonial and colonial Southeast Asia', Comparative Studies in Society and History, vol. 23, no. 2, Apr., 1981, pp. 222-225.
} 
status of the Priyayi. ${ }^{56}$ This means that Samin people endangered their position as an elite class in Javanese society. The 'disrespect' of Saminists to Priyayi can be seen from these conversations such as this one stereotypical:

Priyayi: 'Where have you been?

Saminist: 'From the back.'

Priyayi: 'Where will you going to?

Saminist: 'To the front.'

This conversation shows how Samin people seem to not respect the Priyayi who ask them a question. This is because all people must know that when a person walks, it is automatically from the back to the front. It is often the case that the Priyayi became angry due to their answers such as this one. This also can be seen by another stereotypical conversation:

Priyayi: 'How many cows do you have?'

Saminist: 'I have only two.'

Priyayi: 'You are lying. I know that you have many cows'

Saminist: 'I am not lying. I have only two cows, male and female.'

or

Priyayi: 'How many children do you have?'

Saminist: 'I have only two.'

Priyayi: 'You are lying. I know that you have many children.'

Saminist: 'I am not lying. I have only two children, male and female.'

Yet another conversation between Priyayi and Saminist in the District Court shows how Samin people tend to reject all arguments of Priyayi ${ }^{57}$

Priyayi: 'You still owe the state 90 cents.'

Saminist: 'I have not borrowed anything from the state.'

Priyayi: 'You have to pay taxes though?'

Saminist: 'Wong Sikep (i.e. the Saminist) knows no taxes.'

and

Priyayi: 'Are you crazy or are you pretending to be crazy?'

Saminist: 'I am not crazy nor do I pretend to be.'

Priyayi: 'You used to pay taxes; why not now?'

Saminist: 'The past is the past, now is now. Why doesn't the state stop asking for money?'

Priyayi: 'The state uses money for the native population. If the state did not have enough money, it would be impossible to maintain the roads properly.

Saminist: 'If we find the state of the roads troubling us, we we'll fix them ourselves.'

Priyayi: 'So you won't pay tax?'

Saminist: 'Wong Sikep knows no tax.'

and

${ }^{56}$ W. F. Wertheim \& The Siauw Giap, 'Social Change in Java, 1900-1930', Pacific Affairs, vol. 35, no. 3, Autumn, 1962, pp. 224-225.

${ }^{57}$ Benda \& Castles, 'The Samin Movement', p. 225. 
Priyayi: 'The District Court orders you to pay your debt to the state. If you have not paid within 8 days ... your goods will be seized. Go!'

Saminist: 'As far as I know, I have not borrowed anything from the state.'

(The goods were sold. From the proceeds, the taxes owing were paid; the rest of the money was to be returned to the owners, but they would not accept it).

Saminist: 'As far as I know, I haven't sold anything...'

For all conversations that I have presented, it is clear that Samin people often confront Priyayi.

Their speaking style was learned from Samin Soerantiko. When Soerantiko and Surowiryo were arrested by Raden Pranolo because they claimed themselves to be Ratu (the king) and Patih (the prime minister) in Java, Soerantiko and Surowiryo said to Pranolo, 'Yes, I am a king, but the king for my wife. Yes, I am a prime minister, but the prime minister for my wife '. ${ }^{58}$ The Samin people who always speak to the point made the Priyayi embarrassed when they did not know how to answer back. As a result, they used violence to oppress them. The conflict between Samin and Priyayi also shows that Samin seem challenge the Priyayi and did not acknowledge their authority and power. It is therefore possible that the Priyayi also contributed to the rumours about 'virginity tests' and 'stray marriages' in Samin society.

\section{SAMIN AND THE NEW ORDER REGIME}

The New Order regime of the Soeharto era was well known for its anti-communism. ${ }^{59}$ Many 'communists' were killed without trial, many other detained for extended periods. Samin society, which has a similar egalitarian and communal worldview, was also accused by the regime of being communists. ${ }^{60}$ That is why the government punished and intimidated them. Many Samin people in the past had trouble with the police and the military. Even though more recently, the government has said that this community are 'only Samin' and not communist, the effect of accusation still adheres to this community. ${ }^{61}$ Benda and Castles believe that the socialism of this community was purely a village phenomenon, without influence from modern socialism. ${ }^{62}$

The Samin resisted the New Order regime as they had the earlier colonial regime. For example, they refused to send their children to the schools, refused to marry using the government laws, refused to obtain identity cards, birth certificates and marriage certificates. Learning from the past resistance of the Samin to the colonial regime, the New Order regime tried to diminish this community.

The other reason why the regime oppressed this community is because this community is a 'primitive society', which will create a 'dirty image' of Indonesia. The Soeharto leadership wanted to lead Indonesia as a modern state. ${ }^{63}$ That is why when Soemarno became Bupati (Head of District) of Blora, he announced that Blora and especially Klopoduwur, is free of Samin. He believed that the Samin life style is old fashioned and if this community still survived, it meant the government failed to develop this community. It is therefore also

\footnotetext{
${ }^{58}$ Interview with Carik Klopoduwur, 22 January 2009.

${ }^{59}$ Wanandi, 'Islam in Indonesia', p. 107; Zuly Qodir, 'Kebhinekaan, Kewargaan, dan Multikulturalisme', Jurnal Unisia, vol. 31, no. 68, 2008, pp. 2-3.

${ }^{60}$ Widodo, 'Samin in the New Order', p. 261.

61 Ibid.

${ }^{62}$ Benda \& Castles, 'The Samin Movement', p. 223.

${ }^{63}$ Harold Crouch, 'Military Politics Under Indonesia's New Order', Pacific Affairs, vol. 45, no. 2, Summer, 1972, pp. 206-207.
} 
possible that the government of the New Order regime also contributed to the creation of rumours about 'virginity tests' and 'stray marriages' in the Samin community, so that they might become marginal and leave their adat and beliefs.

\section{CONCLUSION}

My research shows that the Samin communities have similarity with the family in 'preindustrial times' which gave women higher status. However the rumours about 'virginity tests' and 'stray marriages' made this community became marginal. Those who suffer more through these rumours are women. These rumours emerged and spread due to many reasons. From the social, political and historical context, it is clear that Samin have many enemies. Their enemies attack them based on religion (Islam), their resistance to government (the Dutch government, the New Order regime and the Priyayi), their culture (the dominant Javanese culture), and from their vulnerable marriage system (the Samin Gogol). The Samin communities became the 'common enemy' who have to be defeated. Further study should also seek to investigate all four of the major Samin communities (in Blora, Pati, Kudus and Bojonegoro), and come to more comprehensive conclusions as well as improving understanding of the similarities and differences in interpretation and implementation of Agama Adam in each community. We also need to know more about how the Samin are still able to preserve their beliefs in the face of difficulties and obstacles.

\section{REFERENCES}

Abdullah. 1982. 'Anak orang Samin', in Perjalanan Anak Bangsa: Asuhan dan Sosialisasi dalam Pengungkapan Diri, eds. Aswab Mahasin, Ismed Natsir dan Thamrin Hamdan, Jakarta: LP3ES.

Adas, Michael. 1981. 'From avoidance to confrontation: Peasant protest in precolonial and colonial Southeast Asia', Comparative Studies in Society and History, vol. 23, no. 2, pp. 217-247.

Anderson, Benedict. 1981. 'The Suluk Gațoloco: Part One', Indonesia, vol. 32, pp. 109-150.

Ashe, Geoffrey. 1968. Gandhi: A Study in Revolution, London: Heinemann.

Bakker, D. 1972. 'The Struggle for the Future some Significant Aspects of Contemporary Islam in Indonesia, The Muslim World, vol. 62, no. 2, pp. 126-136.

Beauvoir, Simone de. 1989. The Second Sex, New York: Vintage Books.

Benda, Harry J. \& Castles, Lance. 1969. 'The Samin Movement', in Bijdragen tot de Taal-, Land- en Volkenkunde 125, no. 2, Leiden, pp. 207-240.

Boomgaard, Peter. 1994. 'Colonial forest policy in Java in transition 1865-1916', in The Late Colonial State in Indonesia: Political and economic foundations of the Netherlands Indies 1880-1942, ed. Robert Cribb, Leiden: KITLV Press, pp. 117-137.

Bruner, Edward M. 1974. 'The Expression of Ethnicity in Indonesia', in Urban Ethnicity, ed. Abner Cohen, London: Tavistock Publications, pp. 251-280.

Butler, Judith. 1993. Bodies That Matter, New York: Routledge.

Carey, P.B.R. 1981. Babad Dipanagara: An Account of the Outbreak of the Java War (18251830), Kuala Lumpur: Art Printing Works.

Connell, R. W. 2002. 'Differences and Bodies', in Gender, Cambridge: Polity Press, pp. 2852.

Crouch, Harold. 1972. 'Military Politics Under Indonesia's New Order', Pacific Affairs, vol. 45 , no. 2 , pp. $206-219$. 
Dalton, Dennis. 1993. Mahatma Gandhi: Nonviolent Power in Action, New York: Columbia University Press.

Erikson, Erik H. 1969. Gandhi's Truth, New York: Norton.

Fukushima, Masato. 1987. 'The Closed Language: The Samin Movement and Its Philosophy of Language', Southeast Asian Studies, vol. 24, no. 4, pp. 418-435.

Geertz, Clifford. 1976. The Religion of Java, Chicago: The University of Chicago Press.

Ghufron, 1998. Pengaruh Kepemimpinan Kepala Desa Terhadap Perilaku Keagamaan Masyarakat keturunan Samin di Desa Kemantren Kecamatan Kedungtuban, Kabupaten Blora, Semarang: Fakultas Tarbiyah IAIN Walisongo.

Gough, Kathleen. 1975. 'The Origin of the Family', in Toward Anthropology of Women, ed. Rayna R. Reiter, New York: Monthly Review Press, pp. 51-76.

Howell, Julia Day. 2001. 'Sufism and the Indonesian Islamic Revival', The Journal of Asian Studies, vol. 60, no. 3, pp. 701-729.

Joebagio, Hermanu. 2008. 'Religious Splinter Movement from Historical Perspective', Jurnal Millah (Jurnal Studi Agama), vol. 7, no. 2, pp. 1-14.

Korver, A. Pieter E. 1976. 'The Samin movement and millenarism', Bijdragen tot de Taal-, Land- en Volkenkunde 132, no. 2/3, Leiden, pp. 249-266.

Kroef, Justus M. van der. 1952. 'The Messiah in Indonesia and Melanesia', The Scientific Monthly, vol. 75, no. 3, 1952, pp. 161-165.

Magnis-Suseno, Franz. 1997. Javanese Ethics and World-View: The Javanese Idea of the Good Life, Jakarta: Gramedia Pustaka Utama.

Morgan, D. 1978. Social Theory and The Family, London: Routledge \& Kegan Paul.

Niel, Robert van. 1992. Java Under the Cultivation System, Leiden: KITLV Press.

-------.1981. 'The Effect of Export Cultivations in Nineteenth-Century Java', Modern Asian Studies, vol. 15, no. 1, pp. 25-58.

Putranto, Adi. 2003. 'Pandangan Masyarakat Gunung Kidul Terhadap Pelarian Majapahit Sebagai Leluhurnya', Humaniora, vol. xv, no. 2, pp. 224-233.

Qodir, Zuly. 2008. 'Kebhinekaan, Kewargaan, dan Multikulturalisme', Jurnal Unisia, vol. 31 , no. 68 , pp. 1-13.

Scott, James C. 1997. 'Protest and profanation: Agrarian revolt and the little tradition (Part II)', Theory and Society, vol. 4, no. 2, pp. 211-246.

Shiraishi, Takashi. 1990. 'Dangir's testimony: Saminism reconsidered', Indonesia, vol. 50, pp. 95-120.

Smith-Hefner, N J. 1992. 'Pembaron: An East Javanese Rite of Priestly Rebirth', Journal of Southeast Asian Studies, vol. 23, no. 2, 1992. pp. 237-275.

Subekti, Darmo. 1999. Tradisi Lisan Pergerakan Samin: Legitimasi Arus Bawah Menentang Penjajah, Unpublished Paper, Blora.

Sudikan, Setya Yuwana. 1996. Tradisi dari Blora, Semarang: Citra Almamater.

Wanandi, Jusuf. 2002. 'Islam in Indonesia: Its History, Development and Future Challenges', Asia-Pacific Review, vol. 9, no. 2, pp. 104-112.

Wertheim, W. F. \& Giap, The Siauw. 1962. 'Social Change in Java, 1900-1930', Pacific Affairs, vol. 35, no. 3, Autumn, pp. 223-247.

Widodo, Amrih. 1997. 'Samin in the New Order: The Politics of Encounter and Isolation', in Imagining Indonesia: Cultural Politics and Political Culture, Eds. Jim Schiller \& Barbara Martin-Schiller, Ohio: Center for International Studies, Ohio University, pp. 261-287.

Woodcock, George. 1974. Gandhi, London: Fontana.

Woodward, Mark R. 1989. Islam in Java: Normative Piety and Mysticism in the Sultanate of Yogyakarta. Tucson: The University of Arizona Press. 